\title{
Morpho-Syntactic Error Analysis in Written Compositions of MTB-MLE Policy Students
}

\author{
Joseph E. Padilla ${ }^{1} \&$ Corazon A. Padilla ${ }^{2}$ \\ ${ }^{1 \& 2}$ Department of Liberal Arts and Behavioral Sciences (DLABS), Visayas State University, Visca, \\ Baybay City, Leyte, Philippines \\ Correspondence: Joseph E. Padilla, Visayas State University, Visca, Baybay City, Leyte, Philippines. \\ Email: joseph.padilla@vsu.edu.ph
}

Doi: 10.23918/ijsses.v8i2p39

\begin{abstract}
This study reports the dominant linguistic errors in the written composition of Grade 7 Hiligaynonspeaking students in one of the public secondary schools in the Philippines. Following the initial implementation of the MTB-MLE policy, it attempts to identify the structures of English, especially in the domains of morphology and syntax that may have been influenced by the students' mother tongue. More significantly, it identifies the sources of errors made by students. Questionnaires that contained narrative essay topics were distributed among the respondents for personal narrative writing. Errors were identified, categorized, described, and explained using error analysis method. Forty-four categories of errors were classified to find out the sources of morpho-syntactic errors, dominant errors and weak areas that occurred in written compositions. In terms of surface structures, errors had been identified including addition of unnecessary article, omission of verb, misinformation in word class and misordering of major constituents in sentences. The study identified three sources which triggered learners' errors: intralingual, interlingual and communicative strategy. However, the majority of the errors were attributed to intralingual sources which mainly resulted from lack of grammatical and lexical knowledge and faulty sentence formation.
\end{abstract}

Keywords: MTB-MLE Policy Students, Error Analysis, Linguistic Taxonomy, Morpho-Syntactic Errors

\section{Introduction}

English language learners in the Philippines often struggle to communicate their ideas and, as a result, make mistakes while using the language. One pressing problem among Filipino students particularly in the high school level rests on successful communication of their ideas in the target language. Given the linguistic and cultural diversity in the country, students and teachers are greatly challenged in the teaching and learning process as well as policy makers in implementing a language policy that advances students' competence (Burton, 2013).

Previously, Bilingual Education Policies determined Filipino and English as the language of instruction in schools even though about $80 \%$ of the population does not speak either of these as a first language. The Department of Education (DepEd) first acknowledged the advantages of teaching children in their mother

Received: April 14, 2021

Accepted: May 31, 2021

Padilla, J.E., \& Padilla, C.A. (2021). Morpho-Syntactic Error Analysis in Written Compositions of MTB-MLE Policy Students. International Journal of Social Sciences \& Educational Studies, 8(2), 39-52. 
tongue or first language in 2009. Local and international researches have shown that children learn to talk, read, and write faster in their first language, and that they can pick up a second or third language more easily if taught in their first language (Llaneta, 2018). As a result, the Department of Education (DepEd) questioned the Bilingual Education Policy by issuing an order calling for the institutionalization of Mother Tongue Based Multilingual Education (MTB-MLE) to join the United Nations Educational, Scientific, and Cultural Organization (UNESCO) in upholding the mother tongue of learners as the medium of instruction (Cruz, 2015; Wa-Mbaleka, 2014b as cited in Namanya, 2017). Starting in the first grade, children are taught English and Filipino as subjects concentrating on oral fluency, in addition to their mother tongues or first languages. Filipino and English are adopted as instructional languages beginning in fourth grade. From fourth grade onward, Filipino and English are introduced as languages of instruction while the learners' first language is used as the medium of instruction in all subject areas, with Filipino and English taught separately from pre-kindergarten to grade three (Philippines Department of Education, 2009 as cited in Burton, 2013).

Many researchers had been looking at errors for many years since they were thought to be an issue that needed to be addressed as soon as possible. In fact, these errors can eventually be minimized or avoided when they are identified (Zafara, 2017). This is backed up by behaviorists who agree that when mistakes occur, they can be corrected by providing correct forms (Maicusi, Maicusí, \& López, 2000) because they can be a barrier to language learning. Therefore, Rod Ellis (2008) recommends error analysis as a method to eliminate L1 intervention in the language of ESL learners, citing the obvious benefits for teachers and students interested in English Language Teaching (ELT) in bilingual or multilingual environments.

Hence, this study aimed at examining the errors made by students who have undergone the initial implementation of MTB-MLE policy and have advanced to secondary level in one of the public secondary schools in the Philippines. Further, the prominent morphological and syntactic errors were identified and an overall picture of the students' spread of errors were created. Significantly, the sources of errors were identified in the hope of determining extent of influence of the institutionalization of MTB-MLE in second language learning. As an implication, policy makers would gain insights that could serve as basis in improving language planning policies in the Philippines. Teachers would also gain knowledge on students' language behaviour that would enable them to design materials and activities and employ methods and strategies that would cater their students' specific language needs. Teachers will concentrate only on those particular types of errors that need remedial work, rather than spending time on errors that are not made as often by students, avoiding dissatisfaction in correcting the same problems in writing (i.e., inadequate L2 feedback for students) (Mulligan, 2011).

\section{Literature Review}

In this study, the focus of description is on Error Analysis (EA) which is considered as the first way to investigate L2 acquisition especially in the levels of pronunciation, morphology, vocabulary, and grammar. Brown (1980 in Hasyim, 2002) described error analysis as "the method of observing, analyzing, and classifying the deviations of the rules of the second languages and then revealing the structures run by the learner." Corder's early works, which were published in a series of seminal papers in the 1960s and 1970s, are closely connected with Error Analysis, which he used to explain learners' learning of a second language. Error Analysis is a method of applied linguistics that is used to classify areas of difficulty for 
second language learners by using a formal framework to distinguish between the learners' first and target languages (Corder, 1967; Dulay, 1982). They pointed out that errors were important in three ways: first, they provided knowledge to the instructor about how much the learner had learned; second, they provided proof to the researcher about how language was learned; and third, they served as instruments by which the learner discovered the rules of the target language. Corder (1974) also suggests that most research in the 1970s utilized error analysis as the concern with language teaching continued. Indeed, lots of those who attempted to explore more on L2 acquisition believed that the desire to improve pedagogy was itself a motivation in the study of error analysis. Error analysis has become a valuable tool in first and second language learning research because it has led to the discovery that learners' errors represent a difference in their competence, order of acquisition, and accuracy in order of learning (Usha \& Kader, 2016). Therefore, EA can be considered a fundamental tool in language teaching for reorganizing teachers' perspectives and rethinking their methodologies to close and fill students' gaps (Vasquez, 2007). He also helped in developing a methodology for carrying out an error analysis. These five steps in error analysis as suggested including collection of a sample of learner language, identification of errors, description of errors, explanation of errors, and evaluation of errors. Many studies, however, do not involve Step 5, and evaluating learners' errors has traditionally been treated as a separate problem with its own research methods (Ellis, 1997).

In EA, errors are located and identified by arranging a line-up of utterances created or processed by a learner and selecting the one or ones that appear problematic, that is, those that are possibly erroneous (Yang, 2010). The description of errors can then be done into different classifications. Horney (1998), for one, classified errors into fifteen (15) categories which includes spelling, sentence fragments, syntax, adverbs, punctuation, verbs, lexicon, subject omission, conjunction, articles, nouns, pronouns, prepositions, capitalization, and adjectives. In addition, James (1998) stated that there are four types of error taxonomy: the linguistic category classification, the surface structure taxonomy, the comparative taxonomy, and the communicative effect taxonomy. But the most used bases for descriptive taxonomy are two error taxonomies such as:

\subsection{Linguistic Category Classification}

This category specifies errors in terms of linguistic categories and the location of the error in the target language's overall system depending on the linguistic object that is affected by the errors. It specifies the language part that contains the error. This includes both morphological and syntactic elements.

\subsection{The Surface Structure Taxonomy}

This taxonomy is a classification system based on the ways in which the learner's erroneous version is different from the presumed target version. This taxonomy is a classification scheme based on the differences between the learner's incorrect version and the assumed target version. Omission, addition, misformation, and misordering are the four forms of errors defined by James (1998). The absence of an object that must appear in a well-formed utterance is known as omission. The existence of an object that must not appear in well-formed utterances is referred to as addition. Misinformation is when a morpheme or structure is used incorrectly, and misordering is when a morpheme or group of morphemes is placed incorrectly in an utterance. These two forms of error taxonomy will be included in this analysis. 
Further, to analyse errors committed by learners, it is necessary to determine the sources. Brown (2000) states four major sources of error or causes of errors, namely: interlingual transfer, intralingual transfer, communication strategy, and induced. Interlingual errors, he claims, are caused by mother tongue factors. Interlingual transfers are the causes of errors caused by the learners' native language (mother tongue) interfering with the language they are learning. They also translate their mother tongue's system into a foreign language. As a result, they often make mistakes when pronouncing English words because they are speaking in a foreign language using their mother tongue method. Intralingual errors are committed when learners are ignoring a target language form on any level and class. Intralingual transfer, on the other hand, are kinds of transfer that are caused by target language or the rule within the foreign language itself. According to (Richards, 1974), through interaction with the surface structure of English and teaching situation, learning and teaching strategies, individually and in combination, form some of the required and important conditions for the learner to produce those groups of sentences. Another source of error is communication strategy, which refers to the deliberate use of verbal or nonverbal mechanisms to communicate a concept when exact linguistic forms are not readily accessible to the learner at a particular point of communication. Another source of error is induced and is distinct from the two other origins or causes of errors, interlingual and intralingual transfers. Induced may be caused by a student who consistently makes mistakes due to a teacher's deceptive description, a textbook's flawed presentation of a structure or phrase, or even a pattern that was rotary memorized in a drill but not properly contextualized. According to Brown (2000), they are the product of being deceived by the way teachers include meanings, examples, explanations, and practice opportunities. However, since the researchers have restricted access to the instructional materials used, teachers' backgrounds, and other contributors to induced cause of error, the origins of errors are limited to the first three contributors, such as interlingual, intralingual, and communication strategy.

\section{Method}

This study utilized the descriptive-evaluative research design applying a cross-sectional approach. According to Ellis (1997), majority of studies utilizing the Error Analysis as method of analysis have been cross-sectional. It was conducted in one of the public secondary schools in the District of Ilog 1, Division of Negros Occidental. A stratified random sampling technique was used to determine the respondents from the sample size of forty-nine (49) using Sloven's formula. They were taken from the 146-total population of Grade 7 students who were purposely chosen as participants of the study as they were the first batch of students who graduated in the primary level since the institutionalization of MTB-MLE policy in the Philippines.

To obtain data, respondents were asked to write a personal narrative about some relatable topics to elicit sentences to be examined. Topics were adapted from K12 Reading Instruction Resources' narrative essay topics in order to encourage students to write memorable written narratives. In conducting the study, a letter of permission was sought from the school principal together with the letter of consent from the participants. Gathering and collection were a one-day session where questionnaires were distributed for personal narrative writing. The researchers located the suspicious utterances and decided whether the utterance in question was erroneous or not by looking into the frequency of error occurrence. Rules of the General American English for pronunciation, and theories of general linguistics and Turton's (1995) ABC 
of Common Grammatical Errors for syntax served as bases in identifying errors. The collected data from the writing samples which contained errors were categorized and classified into different error categories. All errors were classified into nine different error categories as suggested by Horney (1998). There were 15 categories of errors which were classified and analyzed in this study. The most prominent morphological and syntactic errors made by the respondents were tallied using a simple frequency distribution table. Then explanation of errors was done by looking into their sources using Brown's (2000) and James', Scholfield's, Garret's, and Griffiths' in Yuniarti (2009) classifications.

\section{Results and Discussion}

Morphology and syntax (morpho-syntax) errors are technical errors found on the surface level of language and in reference to the conventions of grammar of a certain language. Findings of the study revealed a total of 1366 errors. Out of fifteen (15) morpho-syntactic error categories by Horney (1998), most commonly committed errors were on the use of verbs (26.43\%). Based on the table below, other prominent errors found in the students' writing composition were associated with spelling (20.50\%), capitalization $(16.11 \%)$ then prepositions $(8.05 \%)$. The fifth highest ranking error found was in syntax $(7.76 \%)$ with errors on punctuation on the sixth with $6.08 \%$. The error rates with pronouns, lexicon, articles, conjunction, and sentence fragments had moderate error frequency and percentage whereas, the least predominant error committed was found in the use of nouns with $0.51 \%$. Moreover, there were no recorded errors on adverbs, adjectives, and subject omission. 
Table 1: Error categories, frequency, percentage of errors, and examples

\begin{tabular}{|c|c|c|c|c|}
\hline $\begin{array}{l}\text { Error } \\
\text { Categories }\end{array}$ & Frequency & $\begin{array}{l}\text { Percentage } \\
(\%)\end{array}$ & $\begin{array}{l}\text { Order } \\
\text { Rank }\end{array}$ & Examples \\
\hline Spelling & 280 & 20.50 & 2 & ...my fewforite friend is Jezreel. \\
\hline $\begin{array}{l}\text { Sentence } \\
\text { Fragments }\end{array}$ & 10 & 0.73 & 11 & $\begin{array}{l}\text { When my school in the Dankalan } \\
\text { Grade } 1 .\end{array}$ \\
\hline Syntax & 106 & 7.76 & 5 & $\begin{array}{l}\text { Please guide me and follow my wish } \\
\text { this Christmas, Christmas is your } \\
\text { birthday. }\end{array}$ \\
\hline Adverbs & 0 & 0 & - & - \\
\hline Punctuation & 83 & 6.08 & 6 & In my first day of school Im excited. \\
\hline Verbs & 361 & 26.43 & 1 & $\begin{array}{l}\text {...because my tito die yesterday... } \\
\text { I want to experience if what feeling... }\end{array}$ \\
\hline Lexicon & 53 & 3.88 & 8 & $\begin{array}{l}\text { During examination my classmate, } \\
\text { school mate... } \\
\text { One day I feelings her... } \\
\text { I see my new transferer classmate... }\end{array}$ \\
\hline $\begin{array}{l}\text { Subject } \\
\text { Omission }\end{array}$ & 0 & 0 & - & - \\
\hline Conjunction & 15 & 1.10 & 10 & $\begin{array}{l}\text { And after shopping we go home but } \\
\text { I'm so very happy. }\end{array}$ \\
\hline Articles & 45 & 3.29 & 9 & $\begin{array}{l}\text {...birthday party is going to the } \\
\text { Jollibee. }\end{array}$ \\
\hline Nouns & 7 & 0.51 & 12 & $\begin{array}{l}\text { I play many sports like basketball, } \\
\text { volleyball... }\end{array}$ \\
\hline Pronouns & 76 & 5.56 & 7 & $\begin{array}{l}\text {...but me and her could not close... } \\
\text {...many dogs in the street who bark } \\
\text { me... }\end{array}$ \\
\hline Prepositions & 110 & 8.05 & 4 & I was new on class... \\
\hline Capitalization & 220 & 16.11 & 3 & $\begin{array}{l}\text { Last year when i was grade } 6 . . . \\
\text { first day of school I am happy... }\end{array}$ \\
\hline Adjectives & 0 & 0 & - & - \\
\hline Total & 1366 & 100 & & \\
\hline
\end{tabular}

The prominent errors identified could be deemed common to Filipino second language learners as other studies in the Philippines have parallel findings. Alinsunod (2014) conducted a study which primarily focuses on writing errors of Engineering students. She reported that difficulties experienced by the ESL students are not easy to escape. Aliweng (2008) conducted a similar study on syntactical analysis and found that the most common errors made by freshmen students at BSBT College were in grammar, 
sentence structure, and mechanics, with the most common errors being past tense of the verb, subject-verb agreement, misuse/omission of conjunctions and prepositions, and word order.

\subsection{Surface Structure Taxonomy}

James (1998) proposes that the learners' erroneous version is different from the presumed target version. This taxonomy works on mechanisms in which surface forms are modified or altered in erroneous utterances (Tizazu, 2014). This classification of errors includes omission, addition, misinformation, and misordering.

\subsubsection{Omission}

Omission errors refer to the absence of an item that must appear in a well-formed utterance. Of which, the most committed omission errors were on punctuations (27.48\%), followed by linking verbs (21.62\%), and prepositions $(17.57 \%)$. There were moderate frequency and percentage of errors committed among helping verbs $(8.11 \%)$, articles $(7.21 \%)$, pronouns $(5.41 \%)$, and conjunctions (3.60\%). A few errors were made by students among relative pronouns $(2.70 \%)$ and main verbs $(1.80 \%)$. The following are some of the examples:

1. There so many people around my grandfather...

2. In my first day of school Im excited.

\subsubsection{Misinformation}

Misinformation errors refer to the use of a wrong form of a morpheme or a structure in an utterance. Among which, the top five committed misinformation errors were faulty verb tense $(54.59 \%)$, wrong use of prepositions (12.01\%), split (5.68\%), faulty subject-verb agreement (4.59\%), and faulty case of pronouns $(4.37 \%)$. Some traces of errors were also made on the use of pronouns $(2.18 \%)$, conjunctions (1.53\%), fragments $(2.18 \%)$, nouns $(1.53 \%)$, linking verb (1.09\%), 'if clause' construction (1.09\%), compounding $(1.75 \%)$, clipping $(0.66 \%)$, and functional shifting $(0.87 \%)$. Sample sentences are shown as follows:

1. And after shopping we go home but I'm so very happy.

2. ...many dogs in the street who bark me...

3. I want to experience if what feeling...

4. One day I feelings her...

5. I see my new transferer classmate...

6. ...high school life is so very funny.

\subsubsection{Addition}

The existence of an item or a form that must not appear in a well-formed utterance is referred to as addition. On this, the following errors occurred in students' paper: unnecessary use of articles (29.90\%), unnecessary of preposition (16.49\%), unnecessary use of linking verb (15.46), unnecessary use of phrase (13.40), unnecessary use of pronoun (13.40\%), and unnecessary use of helping verb (11.34\%). Some examples are as follows: 
1. My first day of school it was so very exciting...

2. When I was a grade 4 , I join playing volleyball.

3. After two days I was recovering with my wound.

\subsubsection{Misordering}

The incorrect placement of a morpheme or group of morphemes in a given utterance causes misordering errors. On this case, there were 36 instances of wrong word order. Examples are as follows:

1. I wish a celebration party birthday.

2. When that night I am walking alone, after practice.

\subsubsection{Surface Structure Taxonomy Summary of Errors}

Figure 1 shows that majority of the errors made involves misinformation. Some were errors in regularization where students did not follow transformation rules such as that of verbs and countable or uncountable noun. There were also instances of archi-form selection of one member of a class of form to represent other on the class. With omission, students have generally omitted punctuations and grammatical morphemes including inflections (-s, -ed, -ing), the article (a, an, the), verb auxiliaries (is, am,are, will, can, must etc), preposition (in, on, at, etc) much more frequently than content words such as nouns, verbs, adjectives, and adverbs. Further, there were 97 cases of errors involving addition. Regularizations, double markings, and simple addition were kinds of addition error observed in the students' written compositions. Lastly, there were few cases of misordering errors with the incorrect placement of a morpheme in students' constructed sentences.

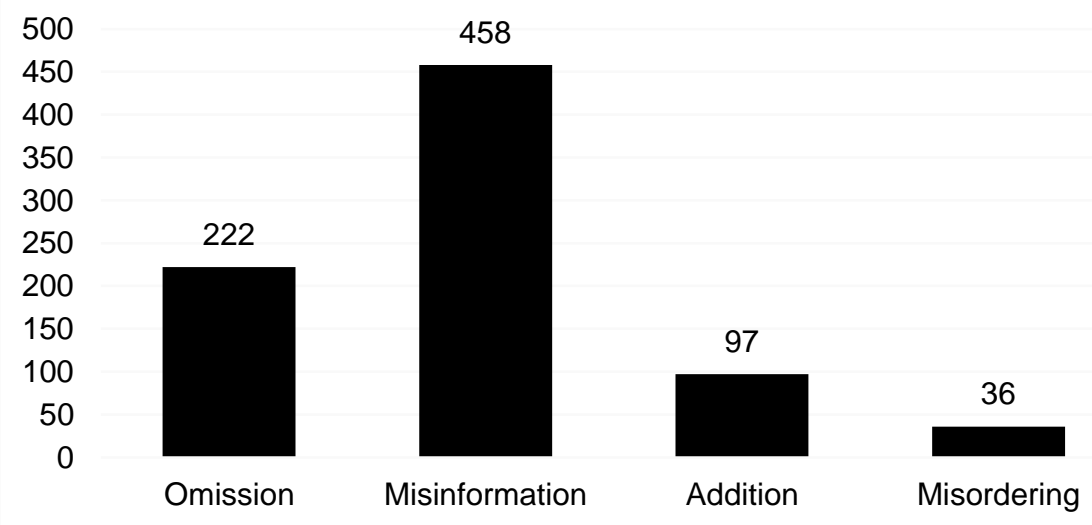

Figure 1: Summary of errors per surface structure taxonomy category

\subsection{Sources of Errors}

Given the number of descriptions for different kinds of errors, the researchers found it beneficial to move further and identify sources of errors. It has also been understood that the nature of errors implicates the existence of other reasons for errors to occur. Muriel (2006) stressed the importance of understanding why 
a mistake was made in any effort to better understand the process of second language learning and improve the way a second language is taught (pedagogical purpose). Based on Brown's (2000) classification, the researchers identified three (3) sources of errors in this analysis. They are interlingual, intralingual, and multilingual, and communication strategy.

\subsubsection{Interlingual}

Errors that are committed with interference of the native language or the mother-tongue are referred as interlingual. They occur because of the negative transfer of the student's native language, which in this case is the Hiligaynon dialect, to the target language. 545 interlingual errors were identified and among them were errors on wrong order, choice of words, code-switching, wrong spelling, capitalization of pronoun "I". In the succeeding table, some examples of interlingual errors with their frequency count, correct forms, and Hiligaynon translation are shown. Sentences with asterisk contain errors made by the students.

Table 2: Interlingual errors and their category, their frequency count, correct forms and Hiligaynon translation

\begin{tabular}{|l|l|l|l|}
\hline Error Category & \multicolumn{2}{|l|}{ Example Sentences } & Hiligaynon Translation \\
\cline { 2 - 3 } & Students' Sentences & Correct Form & \\
\hline Wrong Word Order & $\begin{array}{l}\text { *I wish a celebration } \\
\text { party birthday. }\end{array}$ & $\begin{array}{l}\text { I wish for a } \\
\text { birthday party } \\
\text { celebration. }\end{array}$ & $\begin{array}{l}\text { Nagahandum ako sang isa } \\
\text { ka selebrasyon sa } \\
\text { kasadyahan sang akon } \\
\text { kaadlawan. }\end{array}$ \\
\hline Wrong Choice of Word & $\begin{array}{l}\text { *I love to trip to any } \\
\text { place. }\end{array}$ & $\begin{array}{l}\text { I love to travel to } \\
\text { any place. }\end{array}$ & $\begin{array}{l}\text { Gusto ko maglakbay biskan } \\
\text { diin nga lugar. }\end{array}$ \\
\hline Code-Switching & $\begin{array}{l}\text { *I found my first pet } \\
\text { in the sementeryo. }\end{array}$ & $\begin{array}{l}\text { I found my first } \\
\text { pet at the } \\
\text { cemetery. }\end{array}$ & $\begin{array}{l}\text { Akon nakita ang una ko nga } \\
\text { hinuptanan sa sementeryo. }\end{array}$ \\
\hline Wrong Spelling & $\begin{array}{l}\text { *My fivoret party } \\
\text { I'm going Bicheses } \\
\text { and I'm soewming. }\end{array}$ & $\begin{array}{l}\text { My favourite party } \\
\text { is in the beaches } \\
\text { and go swimming. }\end{array}$ & $\begin{array}{l}\text { Ang paborito ko nga } \\
\text { kinasadya amo didto sa } \\
\text { baybayon kag ang } \\
\text { magapaligo. }\end{array}$ \\
\hline $\begin{array}{l}\text { Pronoun "I" } \\
\text { Capitalization }\end{array}$ & $\begin{array}{l}\text { *When i first } \\
\text { climbing on the tree i } \\
\text { had a little scared } \\
\text { because this was so } \\
\text { tall }\end{array}$ & $\begin{array}{l}\text { When I first } \\
\text { climbed the tree, I } \\
\text { was a little scared } \\
\text { because it was so } \\
\text { tall. }\end{array}$ & $\begin{array}{l}\text { Sang una ako nagtaklas sa } \\
\text { kahoy, nahadlok ako gamay } \\
\text { tungod ini ang mataas. }\end{array}$ \\
\hline
\end{tabular}

\subsubsection{Intralingual}

Majority of errors identified were intralingual with the frequency count of 706 . There were errors that could not be traced back to their L1 because some were caused by incorrect or incomplete target language learning rather than language transfer. They may be the product of the impact of one target language object 
on another. Intralingual errors represent general rule learning characteristics such as incorrect generalization, incomplete rule implementation, and failure to learn conditions under which rules apply. These errors include unnecessary use of phrase, pronoun, and helping verb, faulty "if clause" construction, faulty pronoun-antecedent agreement, and faulty number of nouns. Brown (2000) asserts that errors that do not represent the structure of their native language (NL) or mother tongue (MT) are triggered by intralingual intervention from the target language (TL) and AlTamimi (2006 as cited in Al-Khresheh, 2016) confirms this. Table 3 shows some examples of intralingual errors with their frequency count, correct forms, and Hiligaynon translation are shown. Sentences with asterisk contain errors made by the students.

Table 3: Intralingual errors and their category, their frequency count, correct forms and Hiligaynon translation

\begin{tabular}{|c|c|c|c|}
\hline \multirow[t]{2}{*}{ Error Category } & \multicolumn{2}{|l|}{ Sentences } & \multirow[t]{2}{*}{ Hiligaynon Translation } \\
\hline & Students' Sentences & Correct Form & \\
\hline Faulty Verb Tense & $\begin{array}{l}\text { *I'm so sad yesterday } \\
\text { because my tito die } \\
\text { yesterday. }\end{array}$ & $\begin{array}{l}\text { I was so sad } \\
\text { yesterday because my } \\
\text { tito died yesterday. }\end{array}$ & $\begin{array}{l}\text { Grabe guid akon kasubo } \\
\text { kagapon kay napatay } \\
\text { akon tiyo. }\end{array}$ \\
\hline $\begin{array}{l}\text { Wrong Use of } \\
\text { Preposition }\end{array}$ & $\begin{array}{l}* \text { My most exciting } \\
\text { moment playing sports } \\
\text { is volleyball to my } \\
\text { friends. }\end{array}$ & $\begin{array}{l}\text { My most exciting } \\
\text { moment is playing } \\
\text { sports like volleyball } \\
\text { with my friends. }\end{array}$ & $\begin{array}{l}\text { Ang } \\
\text { pinakamakakulunyag } \\
\text { nga tion sa akon amo } \\
\text { ang maghampang sang } \\
\text { isport kaangay sang } \\
\text { volleyball upod sa akon } \\
\text { mga abyan. }\end{array}$ \\
\hline $\begin{array}{l}\text { Absence of Linking } \\
\text { Verb }\end{array}$ & $\begin{array}{l}\text { *One day I am going } \\
\text { first to school no body } \\
\text { are there. }\end{array}$ & $\begin{array}{l}\text { One day I was going } \\
\text { to school, but nobody } \\
\text { was there. }\end{array}$ & $\begin{array}{l}\text { Isa ka adlaw naglakat } \\
\text { ako sa buluthuan } \\
\text { ugaling wala sang taho } \\
\text { didto. }\end{array}$ \\
\hline $\begin{array}{l}\text { Omission of } \\
\text { Preposition }\end{array}$ & $\begin{array}{l}\text { *I'm very happy my } \\
\text { first day of school } \\
\text { becouse I'm very } \\
\text { excited. }\end{array}$ & $\begin{array}{l}\text { I'm very happy on my } \\
\text { first day of school } \\
\text { because I'm very } \\
\text { excited. }\end{array}$ & $\begin{array}{l}\text { Grabe akon kalipay sa } \\
\text { una nga adlaw sang } \\
\text { klase kay ako nakunyag. }\end{array}$ \\
\hline $\begin{array}{l}\text { Unnecessary Use of } \\
\text { Articles }\end{array}$ & $\begin{array}{l}\text { *When I was a grade } 4, \\
\text { I join playing } \\
\text { volleyball. }\end{array}$ & $\begin{array}{l}\text { When I was grade } 4, \\
\text { I joined playing } \\
\text { volleyball. }\end{array}$ & $\begin{array}{l}\text { Sang ako grade } 4, \text { nag- } \\
\text { intra ako hampang sang } \\
\text { volleyball. }\end{array}$ \\
\hline $\begin{array}{l}\text { Faulty subject-Verb } \\
\text { Agreement }\end{array}$ & $\begin{array}{l}* \text { My favourite sports } \\
\text { are balliball and } \\
\text { basketball. }\end{array}$ & $\begin{array}{l}\text { My favourite sports } \\
\text { are volleyball and } \\
\text { basketball. }\end{array}$ & $\begin{array}{l}\text { Ang akon paborito nga } \\
\text { isports amo ang } \\
\text { volleyball kag } \\
\text { basketball. }\end{array}$ \\
\hline $\begin{array}{l}\text { Faulty Case of } \\
\text { Pronoun }\end{array}$ & $\begin{array}{l}\text { *My summer vacation } \\
\text { is happy because me } \\
\text { and my cousins } \\
\text { sometimes meet. }\end{array}$ & $\begin{array}{l}\text { My summer vacation } \\
\text { is happy because my } \\
\text { cousin and I } \\
\text { meet sometimes. }\end{array}$ & $\begin{array}{l}\text { Malipayon ang akon } \\
\text { bakasyon sa tingadlaw } \\
\text { tungod kon kaisa makita } \\
\text { ko akon pakaisa. }\end{array}$ \\
\hline
\end{tabular}




\begin{tabular}{|l|l|l|l|}
\hline $\begin{array}{l}\text { Absence of Helping } \\
\text { Verb }\end{array}$ & $\begin{array}{l}\text { *The day we going to } \\
\text { cemetery I cry and cry }\end{array}$ & $\begin{array}{l}\text { I cried and cried on } \\
\text { the day we were } \\
\text { going to the } \\
\text { cemetery, }\end{array}$ & $\begin{array}{l}\text { Naghibi ko kag naghibi } \\
\text { sa adlaw nga kami } \\
\text { padulong sa sementeryo. }\end{array}$ \\
\hline Omission of Article & $\begin{array}{l}\text { *Before we start, we } \\
\text { pray that Lord guide in } \\
\text { this competition. }\end{array}$ & $\begin{array}{l}\text { Before we started, we } \\
\text { prayed that the Lord } \\
\text { would guide us. }\end{array}$ & $\begin{array}{l}\text { Ante's kami nagsugod, } \\
\text { kami nagpangamuyo sa } \\
\text { Ginoo nga kami iya } \\
\text { tuytuyan. }\end{array}$ \\
\hline $\begin{array}{l}\text { Unnecessary Use of } \\
\text { Preposition }\end{array}$ & $\begin{array}{l}\text { *I want to see my ante } \\
\text { like ante Sally because } \\
\text { she loves to me. }\end{array}$ & $\begin{array}{l}\text { I want to see my } \\
\text { auntie like auntie } \\
\text { Sally because she } \\
\text { loves me. }\end{array}$ & $\begin{array}{l}\text { Gusto ko Makita akon } \\
\text { nga tiya pareho kay tiya } \\
\text { Sally tungod } \\
\text { ginapalangga niya ako. }\end{array}$ \\
\hline $\begin{array}{l}\text { Unnecessary Use of } \\
\text { Linking Verb }\end{array}$ & $\begin{array}{l}\text { *After two days I was } \\
\text { recovering with my } \\
\text { wound. }\end{array}$ & $\begin{array}{l}\text { After two days, I } \\
\text { recovered from my } \\
\text { wound. }\end{array}$ & $\begin{array}{l}\text { Pagkatapos sang duwa } \\
\text { ka adlaw, nag-ayo akon } \\
\text { pilas. }\end{array}$ \\
\hline
\end{tabular}

\subsubsection{Communication Strategy}

Students, when faced with some difficulties, employ systematic techniques to express his own idea (Corder, 1978 as cited in Wei, 2011). They adopt conscious plans for solving communicative problems in reaching a particular communicative goal known as communicative strategies. These strategies play an important role in communication and have significant influence on second language learning and acquisition. In this study, there were ten (10) identified errors that resulted from communication strategies of students. All of them were sentence fragments which were the result of not being able to make complete sentence. The students, to be able to express their thoughts in complete sentences, employ reduction strategy and make use of every available lexicon. They combine and structure them without minding the rules of the target language nor of the native language. Shown in Table 4 is an example of communication strategy-based error with the frequency count, correct form, and Hiligaynon translation. The sentence with asterisk contains errors made by the students.

Table 4: Communication strategy-based errors and their category, their frequency count, correct forms, and Hiligaynon translation

\begin{tabular}{|c|c|c|c|}
\hline \multirow{2}{*}{$\begin{array}{l}\text { Error } \\
\text { Category }\end{array}$} & \multicolumn{2}{|l|}{ Sentences } & \multirow[t]{2}{*}{ Hiligaynon Translation } \\
\hline & $\begin{array}{l}\text { Students' } \\
\text { Sentences }\end{array}$ & Correct Form & \\
\hline Sentence Fragment & $\begin{array}{l}\text { *Because the dog } \\
\text { is help. I'm happy } \\
\text { chasing chickens. }\end{array}$ & $\begin{array}{l}\text { I am happy because the } \\
\text { dog helps in chasing the } \\
\text { chickens. }\end{array}$ & $\begin{array}{l}\text { Ako malipayon kay ang ido } \\
\text { nagbulig lagas sang mga } \\
\text { manok. }\end{array}$ \\
\hline
\end{tabular}

\subsubsection{Summary of Sources of Errors}

Having the errors identified, categorized and described, explaining why certain errors occurred was then done. The sources identified were interlingual which results when learners of a second or foreign language 
make mistake in the target language by effect of his/her mother tongue as shown in wrong word order, wrong choice of word, code-switching, wrong spelling, and not capitalizing the pronoun "i". Another source is intralingual, which is more concerned with proper grammar use and happens after a significant portion of the second language has been learned. This is where they begin to make unintentional errors in the English language, such as irregular verbs, the right or incorrect use of posts, the absence of a connecting verb, the lack of a preposition, faulty subject-verb agreement, fragment, and faulty pronoun-antecedent agreement. Finally, a communicative strategy refers to the deliberate use of verbal or nonverbal mechanisms to communicate a concept when exact linguistic types are not readily accessible to the learner at a particular point of conversation, as in fragment and run-on sentence constructions.

$$
\begin{array}{r}
800 \\
700 \\
600 \\
500 \\
400 \\
300 \\
200 \\
100 \\
0
\end{array}
$$

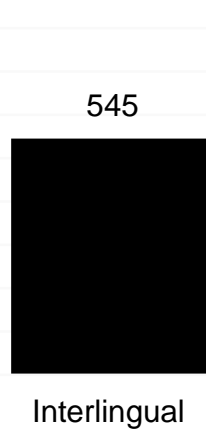

Figure 2: Summary of sources of errors based on frequency count.

\section{Conclusion}

In sum, this study found that the prominent morpho-syntactic errors include faulty verb tense, wrong use of preposition, absence of linking verb, omission of preposition, and unnecessary use of articles. There was also a considerable number of errors involving spelling, word choice, code-switching, faulty capitalization, punctuation omission, and run-on sentence.

Findings also revealed that misinformation was the most common type of students' errors occurred in the students' writings. Some were errors in regularization where students did not follow transformation rules such as that of verbs, countable or uncountable noun and some archi-form selection of one member of a class of form to represent other on the class. Furthermore, students used the incorrect forms of the morpheme and structure. It meant that the students committed the errors because they have not mastered the English grammar.

Furthermore, this study found that intralingual transfer was the dominant source of the students' error. It is considered as the major barrier of learning the second language among the MTB-MLE policy students in this study. This occurs during the learning process at the stage when the learners have not really acquired the knowledge. Findings show that the students might have difficulty in mastering the target language because of the rules within the target language itself not because of mother tongue interference. These errors could not be traced back to Hiligaynon since some are the product of incorrect or incomplete target language learning rather than language conversion. They may be the product of the impact of one target language object to another. Intralingual errors reflect general characteristics of rule learning such as faulty 
generalization, incomplete application of rules and failure to learn conditions under which rules apply. These errors occur during the learning process of the second language at a stage when the learners have not really acquired the rules. This supports other research findings that when a child's mother tongue is the primary language of instruction in primary school, their ability to learn a second language does not suffer.

\section{References}

Al-Khresheh, M. H. (2016). A review study of error analysis theory. International Journal of Humanities and Social Science Research, 49-59.

Brown, D. (2004). Language assessment: Principles and classroom practices. San Francisco.

Brown, H. (2000). Principles of language learning and teaching. New Jersey: Prentice Hall Inc.

Burton, L. A. (2013). Mother tongue-based multilingual education in the Philippines: Studying top-down policy implementation from the bottom up.

Deterding, D. (2006). The North wind versus a wolf: Short texts for the description and measurement of English pronunciation. Journal of the International Phonetic Association, 187-196.

Ellis, R. (2008). The study of second language acquisition (2nd Edition ed.). Oxford: Oxford University Press.

Grisales, M. S., \& Cruz, A. G. (2017). Oral skills development through the use of language learning strategies, podcasting and collaborative work. Gist Education and Learning Research Journal, $32-48$.

Hariri, M. (2012). Taxonomy of morpho-syntactic errors and error analysis. Research Journal of Applied Sciences, Engineering and Technology, 4856-4860.

Hill, J. D., \& Björk, C. L. (2016). Classroom instruction that works with english language learners participant's workbook. USA: Association for Supervision and Curriculum Development.

Llaneta, C. A. (2018, February). University of the Philippines. Retrieved from Teaching in Motehr Tongues: https://www.up.edu.ph/index.php/teaching-in-mother-tongues/

Maicusi, T., Maicusí, P., \& López, M. C. (2000). The error in the second language acquisition.

Mulligan, M. (2011). Error analysis of written and spoken english:practical suggestions. Revista de Lenguas para-Fines Específicos, 402-410.

Namanya, S. J. (2017). The effects of mother tongue-based multilingual education on the English literacy of children in Silang, Philippines. International Forum, 160-177.

Richards, J. C. (1974). Error analysis. Perspectives on second language acquisition. London: Longman.

Tizazu, Y. (2014). A linguistic analysis of errors in learners' compositions: The case of Arba Minch university students. International Journal of English Language and Linguistics Research, 69101.

Touchie, H. Y. (1986). Second language learning errors their types, causes, and treatment. JALT Journal.

Turton, N. D. (1995). ABC of common grammatical errors. Oxford: Macmillan Publishers Limited.

Wei, L. (2011). Communicative strategies in second language acquisition. Sweden: Kristianstad University Sweden.

Yadav, D. M. (2014). Role of mother tongue in second language learning. International Journal of Research, 572-582. 
Yang, W. (2010, May). A tentative analysis of errors in language learning and use. Journal of Language Teaching and Research, 266-268.

Yuniarti, D. A. (2009). A study on the pronunciation of english vowel by english department student. FKIP Muhammadiyah University of Surakarta.

Zafara, A. (2017). Error analysis: A tool to improve English skills of undergraduate students. Islamabad: Elsevier. 